\title{
A inconsistência da Defesa Técnico-Jurídica por "não habilitado" no Processo Administrativo Disciplinar Brasileiro
}

\author{
The inconsistency of technical-legal defense for "not enabled" in \\ the Brazilian Disciplinary Administrative Process
}

\author{
Elieuton Sampaio Gois ${ }^{1}$ \\ Jefferson Carlos Carús Guedes ${ }^{2}$
}

\begin{abstract}
RESUMO
A CF/1988 prevê o devido processo legal, implementado também pelo direito à defesa ampla (de argumentos, de interpretações e de ideias). A amplitude indica a possibilidade de exercitar todas as modalidades de defesa permitidas, inclusive a técnico-jurídica, sendo esta atribuição de profissional habilitado. Tendo por base predominantemente a legislação em vigor e decisões do Supremo Tribunal Federal, sem exclusão da doutrina mais abalizada, expõem-se: A defesa técnico-jurídica é constitucionalmente confiada ao Ministério Público, Advocacia Pública, Defensoria Pública e Advocacia (considerados essenciais à justiça). Sendo a Advocacia essencial, o Advogado é tido como indispensável à promoção da justiça. Assim, no primeiro capítulo, afirma-se que o cumprimento da justiça, necessariamente participativo e democrático, somente é real ao se efetivar os objetivos da República Federativa do Brasil ao mesmo tempo em que se obedecem e fomentam os direitos fundamentais materiais e processuais. $\mathrm{Na}$ sequência, mais precisamente no segundo capítulo, argumenta-se que a dispensa de advogado em processo é excepcional, opção que cabe somente aos titulares do direito à ampla defesa e ao legislador ordinário. Porém, a este é consentida apenas se resultar maiores benefícios àqueles. $\mathrm{Na}$ terceira e última parte deste trabalho, constata-se fundamentadamente que a dispensa de defesa por profissional habilitado em processo administrativo disciplinar prevista no $\S 2^{\circ}$ do art. 164 da Lei ${ }^{\circ}$ 8.112/1990 e na Súmula Vinculante ${ }^{\circ} 5$ do STF, por não garantir ao servidoradministrado os benefícios que a amplitude da defesa lhe reserva, infringe o valor Justiça insculpido na Constituição de 1988.
\end{abstract}

\section{PALAVRAS-CHAVE:}

Ampla defesa, democracia, devido processo legal, justiça, processo administrativo disciplinar.

\begin{abstract}
The CF/1988 provides for due process of law, also implemented by the right to broad defense (of arguments, interpretations and ideas). The breadth indicates the possibility of exercising all permitted defense modalities, including the legal-technical, and this assignment of qualified

\footnotetext{
${ }^{1}$ Mestre em Direito e Políticas Públicas (UniCEUB); Membro do Grupo de Pesquisa Direito Ambiental e Desenvolvimento Sustentável. Pós-graduado em Direito Penal/Processo Penal (UniCEUB) e Direito Processual Civil (UNIFOR). Graduado em Direito (UFCe). Analista Judiciário STJ; Ex Delegado de Polícia, BA. Nomeado Advogado em cargo efetivo do IBRAM e da EMATER-DF.

${ }^{2}$ Doutor em Direito das Relações Sociais - Processual Civil (PUC-SP); Mestre em Direito Processual Civil (PUCSP); Pós-graduado em Direito Processual Civil (PUC-RS). Graduado em Direito (URCAMP). Coordenador do Grupo de Pesquisa ISO - Desigualdade e Justiça Processual. Professor do Doutorado, Mestrado e Graduação do UniCEUB. Advogado e Consultor Jurídico.
} 
professional. Based predominantly on current legislation and rulings of the Federal Supreme Court, without excluding the most authoritative doctrine, the following stand out: The legal and technical defense is constitutionally entrusted to the Public Prosecution Service, Public Advocacy, Public Defender and Advocacy (considered essential to justice). As advocacy is essential, the lawyer is regarded as indispensable to the promotion of justice. Thus, in the first chapter, it is stated that the fulfillment of justice, necessarily participatory and democratic, is only real when the objectives of the Federative Republic of Brazil are fulfilled while obeying and promoting fundamental material and procedural rights. Subsequently, more precisely in the second chapter, it is argued that the dismissal of a lawyer in proceedings is exceptional, an option that rests solely with the right-to-defense and the ordinary legislator. However, it is consented only if it results in greater benefits to those. In the third and last part of this work, it is clearly stated that the waiver of defense by a professional qualified in disciplinary administrative proceedings provided for in $\S 2$ of art. 164 of Law No. 8,112/1990 and in the Binding Precedent No. 5 of the Supreme Court, for not guaranteeing to the server-administrator the benefits that the scope of the defense reserves to him, infringes the justice value inscribed in the 1988 Constitution.

\section{KEYWORDS:}

Wide defense, democracy, due process of law, justice, disciplinary administrative proceeding.

\section{INTRODUÇÃO}

Cabe o Estado dar cumprimento aos ditames constitucionais explícitos e implícitos. Nesse sentido, o legislador infraconstitucional deve obedecer à CF/1988, pois é seu destinatário por excelência. Na formulação de leis, sua interpretação e aplicação, devem, respectivamente, legislador, gestores públicos e membros do judiciário satisfazer os fundamentos e objetivos da República Federativa do Brasil, além de, simultaneamente, proteger e dar execução aos direitos e garantias fundamentais.

Entre os direitos e garantias constitucionais, há o devido processo legal, ${ }^{3}$ a ser concretizado por direitos como o de defesa, qualificado por amplitude, ${ }^{4}$ a todos os interessados envolvidos no processo. A adjetivação referida, por sua vez, materializa-se pelo direito de

\footnotetext{
${ }^{3}$ Art. $5^{\circ}$, LIV, da CF/1988: "ninguém será privado da liberdade ou de seus bens sem o devido processo legal;". Ver: BRASIL. Constituição da República Federativa do Brasil de 1988. Disponível em: http://www.planalto.gov.br/ccivil_03/constituicao/constituicaocompilado.htm. Acesso em: 25 ago. 2017.

${ }^{4}$ Art. $5^{\circ}$, LV, da CF/1988: "aos litigantes, em processo judicial ou administrativo, e aos acusados em geral são assegurados o contraditório e ampla defesa, com os meios e recursos a ela inerentes;"”.
} 
exercitar todas as modalidades de salvaguarda disponíveis e permitidas pelo Direito, entre as quais a técnico-jurídica. De acordo com a CF/1988, a defesa por profissional habilitado é confiada essencialmente ao Ministério Público, Advocacia Pública, Defensoria Pública e Advocacia, considerados "funções essenciais" à promoção e aperfeiçoamento do valor justiça. Nesse diapasão, o advogado é considerado “indispensável”. ${ }^{6}$

Dispensar a presença de advogado em processo não corresponde à regra, devendo ser consentida apenas em situações excepcionais, seja pelo titular do direito ou pelo legislador ordinário. A dispensa de defesa processual técnico-jurídica a ser exercida por profissional habilitado apenas se adéqua à ordem democrática imposta pelo constituinte quando não haja o comprometimento do núcleo essencial da amplitude da defesa, sob pena de mácula do próprio devido processo legal material.

Nesse contexto, o art. $164, \S 2^{\circ}$, da Lei $n^{\circ} 8.112 / 1990$ e a norma contida na Súmula Vinculante $\mathrm{n}^{\circ} 5$ do STF (Supremo Tribunal Federal) preveem a dispensa da atuação de advogado em processo disciplinar administrativo. ${ }^{7}$ Pressupondo a necessidade de dar efetividade aos valores democracia e justiça expressos no texto constitucional, ${ }^{8}$ de suma importância a verificação de compatibilidade do enunciado normativo e da norma contida na jurisprudência do STF com os valores mencionados.

Num primeiro momento, procura-se esclarecer os sentidos de essencialidade e indispensabilidade referentes respectivamente à advocacia e ao advogado, no contexto da realização e aperfeiçoamento do valor justiça democrática. Em seguida, explicita-se o significado de justiça em articulação com demais objetivos da República Federativa do Brasil revelados na CF/1988. Por último, salienta-se a importância da defesa técnico-jurídica realizada por advogado habilitado (manifestação da ampla defesa) para cumprimento do devido processo

\footnotetext{
5 Diz respeito ao Título "Da organização dos Poderes".

${ }^{6}$ Art. 133, da CF/1988: “O advogado é indispensável à administração da justiça, sendo inviolável por seus atos e manifestações no exercício da profissão, nos limites da lei”.

7 Art. 164, § 2 $2^{\circ}$, da Lei $\mathrm{n}^{\circ}$ 8.112/1990: "Para defender o indiciado revel, a autoridade instauradora do processo designará um servidor como defensor dativo, que deverá ser ocupante de cargo efetivo superior ou de mesmo nível, ou ter nível de escolaridade igual ou superior ao do indiciado". Ver: BRASIL. Lei no 8.112, de 11 de dezembro de 1990. Dispõe sobre o regime jurídico dos servidores públicos civis da União, das autarquias e das fundações públicas federais. Disponível em: http://www.planalto.gov.br/ccivil_03/leis/L8112cons.htm. Acesso em: 10 ago. 2017.

Quanto ao enunciado da Súmula Vinculante n ${ }^{\circ}$ 5, ver: BRASIL. Supremo Tribunal Federal. Súmula Vinculante $n^{o}$ 5 - "A falta de defesa técnica por advogado no processo administrativo disciplinar não ofende a Constituição". Tribunal Pleno. DJ 16 maio 2008.

8 Art. $3^{\circ}$, da CF/1988.
} 
legal substancializado, oportunidade em que o enunciado 164 , $\S 2^{\circ}$, da Lei $n^{\circ} 8.112 / 1990$ e a norma manifesta na Súmula Vinculante $n^{\circ} 5$ são confrontados com fundamentos, objetivos e princípios previstos na $\mathrm{CF} / 1988$.

\section{ESSENCIALIDADE DA FUNÇÃO ADVOCATÍCIA PARA O APERFEIÇOAMENTO DA JUSTIÇA}

O título do Capítulo IV, do Título IV, da CF/1988, vai do art. 127, inclusive, ao art. 135, e se encontra assim manifesto: "Das funções essenciais à justiça". O constituinte entendeu que são 4 (quatro) as funções essenciais ${ }^{9}$ à promoção da justiça: Ministério Público, Advocacia Pública, Advocacia ${ }^{10}$ e a Defensoria Pública. Especificamente quanto ao papel da atividade advocatícia, faz-se necessário desvendar os sentidos de "essencial” e de "justiça" para só então expor algumas atribuições constitucionais da advocacia.

\subsection{O conceito de essencial e o significado de justiça no Capítulo IV, Título IV, da CF/1988}

Essencial significa o que “[...] é inerente a algo ou alguém [...] que constitui o mais básico ou o mais importante em algo; [...] fundamental [...] que é necessário, [...] o indispensável [...]". ${ }^{11}$ Literalmente, é esta a importância que o constituinte deu às funções indicadas por ele quanto ao acesso e aperfeiçoamento da justiça. Independentemente do significado desta, o constituinte, diante das possibilidades jurídicas então existentes, indicou as instituições Ministério Público, Advocacia Pública, Advocacia e Defensoria Pública, sem exclusão do Poder Judiciário, como ferramentas imprescindíveis à promoção e aperfeiçoamento

\footnotetext{
${ }^{9}$ Entende-se que o constituinte deu ao termo "funções" o sentido de instituições. Face ao esclarecimento, não se fará uso de aspas entre a palavra funções quando com o significado referido.

${ }^{10}$ O constituinte, no contexto, fez uso do termo "Advocacia" com sentido restrito, pois a atividade advocatícia, em termos gerais, envolve os integrantes da Advocacia-Geral da União, da Procuradoria da Fazenda Nacional, da Defensoria Pública e das Procuradorias e Consultorias Jurídicas dos Estados, do Distrito Federal, dos Municípios e das respectivas entidades de administração indireta e fundacional (art. $3^{\circ}, \S 1^{\text {o }}$, da Lei ${ }^{\circ}$ 8.906/1994). Ver: BRASIL. Lei $n^{\circ}$ 8.906, de 04 de julho de 1994. Dispõe sobre o Estatuto da Advocacia e a Ordem dos Advogados do Brasil (OAB). Disponível em: http://www.planalto.gov.br/ccivil_03/leis/L8906.htm. Acesso em: 25 ago. 2017. ${ }^{11}$ ESSENCIAL. Houaiss eletrônico. Versão multiusuário 2009.8. São Paulo: Objetiva, 2014.
} 
da justiça. Logo, as funções apontadas compreendem complexas estruturas funcionais voltadas a fim mediato: acesso, desenvolvimento e aperfeiçoamento da justiça.

Destarte, as funções referidas não são fim em si mesmas e no que tange à imprescindibilidade para o cumprimento da finalidade indireta - comum a todas - equiparamse em importância. Independentemente da natureza ou origem das funções ditas essenciais, entendê-las desequilibradas entre si, quanto à atribuição a elas conferidas expressamente na Carta Magna, configuraria manifesto desapreço à lógica político-normativa presente na CF/1988. Reconhecê-las, incrementá-las e aperfeiçoá-las (as funções essenciais) não só é juridicamente possível, como compreende um dever-poder endereçado a todo o Estado. Face a isso, sob pena de violação dos objetivos definidos na $\mathrm{CF} / 1988,{ }^{12}$ não devem tais funções, enquanto consideradas imprescindíveis, ser estruturalmente extintas ou mesmo funcionalmente fragilizadas.

As funções mínimas (imprescindíveis) dirigidas ao desenvolvimento e aperfeiçoamento da justiça foram desde logo identificadas na CF/1988. Deve-se dar efetividade a tal regramento constitucional não apenas por razões meramente formais, mas principalmente pela importância sócio-política do fim Justiça à qual as funções devem atender. Tal escopo reveste-se de conteúdo valorativo, ${ }^{13}$ o qual manifesta destacadamente os objetivos fundamentais da República Federativa do Brasil. Pois, num Estado cujas pretensões incluem uma duradoura sociedade livre, justa, democrática, solidária e desenvolvida socioeconomicamente, os meios precisam necessariamente ser capazes de eficientemente realizar a pretensão. Nessa perspectiva, a opção por funções da elevação do Ministério Público, Advocacia Pública, Advocacia e Defensoria Pública não poderia deixar de corresponder a propósito igualmente imponente, tal como justiça.

\footnotetext{
${ }^{12}$ Entre outros objetivos, destacam-se os presentes no inciso I do art. $3^{\circ}$, da CF/1988: "Constituem objetivos fundamentais da República Federativa do Brasil: I - construir uma sociedade livre, justa e solidária; [...]” (grifos nossos).

${ }^{13}$ O preâmbulo da CF/1988 assim dispõe: “[...] para instituir um Estado Democrático, destinado a assegurar o exercício dos direitos sociais e individuais, a liberdade, a segurança, o bem-estar, o desenvolvimento, a igualdade e a justiça como valores supremos de uma sociedade fraterna, pluralista e sem preconceitos, fundada na harmonia social e comprometida, na ordem interna e internacional, com a solução pacífica das controvérsias, promulgamos $[\ldots] "$.

Conquanto o preâmbulo não possa ser referência à realização de controle de constitucionalidade; segundo entendimento do STF, é relevante por atender à função interpretativa.
} 
Apesar dos vários significados de justiça, ${ }^{14}$ entende-se que no Capítulo IV, do Título IV, da CF/1988, o constituinte reporta-se à aptidão que a aplicação do Direito tem de promover os objetivos do Estado de forma equânime, ao mesmo tempo em que respeita e promove os direitos fundamentais. Noutros termos, a referida justiça parece significar a eficiente relação de adequação entre as demandas sociais e a criação e aplicação das normas, num cenário necessariamente transparente e amplamente democrático. Vê-se, pois, que a justiça à qual o texto constitucional faz alusão, além da motivação pragmática e palpável, é objetivamente verificável e controlável.

Embora, por vezes, justiça possa parecer sinônimo de Poder Judiciário ${ }^{15}$ ou prestação jurisdicional, com eles não se confunde. ${ }^{16}$ Onde houver concreta decisão solucionadora de demandas sociais, há norma, a qual poderá ou não manifestar justiça. Nesse sentido, decisões podem advir de fontes diversas, ${ }^{17}$ estatais ou não estatais. O juízo arbitral, por exemplo, destacase como fonte normativa alheia à estrutura do Estado. ${ }^{18} \mathrm{Na}$ engrenagem estatal, por sua vez, não só o Poder Judiciário, pela função própria que titulariza, confere normatividade aos textos jurídicos, visto que os demais Poderes também exercem igual atribuição, visto que ao interpretarem e aplicarem enunciados jurídicos, podem e devem prestar justiça. Assim sendo, instituições como Ministério Público, Advocacia Pública, Advocacia e Defensoria Pública, igualmente têm o dever não só de defender o acesso à justiça, mas de promove-lo. ${ }^{19}$

\footnotetext{
14 "Podem-se distinguir dois significados principais: i) conformidade da conduta a uma norma; ii) eficiência de uma norma ou de um sistema de normas, entendendo-se por eficiência certa capacidade de possibilitar as relações entre os homens". Conferir em: ABBAGNANO, Nicola. Dicionário de Filosofia. Tradução da $1^{\text {a }}$ edição brasileira coordenada e revista por Alfredo Bosi; revisão da tradução e tradução dos novos textos por Ivone Castilho Benedetti. $5^{\text {a }}$ ed. revista e ampliada. São Paulo: Martins Fontes, 2007.

${ }^{15}$ Kildare Gonçalves Carvalho defende que a garantia constitucional do acesso à justiça "é a inafastabilidade ao acesso ao Judiciário, traduzida no monopólio da jurisdição, ou seja, havendo ameaça ou lesão de direito, não pode a lei impedir o acesso ao Poder Judiciário". Ver: CARVALHO, Kildare Gonçalves. Direito constitucional. $11^{\text {a ed., }}$ rev. e atual. Belo Horizonte: Del Rey, 2005.

${ }^{16}$ Art. 107, § 3 ${ }^{\circ}$, da CF/1988: "Os Tribunais Regionais Federais poderão [...] a fim de assegurar o pleno acesso do jurisdicionado à justiça em todas as fases do processo".

Art. 115, § 2, $\mathrm{CF} / 1988$ : "Os Tribunais Regionais do Trabalho poderão [...] a fim de assegurar o pleno acesso do jurisdicionado à justiça em todas as fases do processo".

Art. $125, \S 6^{\circ}, \mathrm{CF} / 1988$ : "O Tribunal de Justiça poderá [...] a fim de assegurar o pleno acesso do jurisdicionado à justiça em todas as fases do processo".

${ }^{17}$ Quanto às fontes do Direito, adota-se o entendimento de Miguel Reale, o qual afirma que fonte de Direito implica necessariamente subjacente estrutura de poder, a qual garante vigência das normas por imposição, garantida pela eventual aplicação de sanções ao desobediente (grifos nossos). REALE, Miguel. O direito como experiência. Introdução à epistemologia jurídica. $2^{\mathrm{a}}$ ed. São Paulo: Saraiva, 2002.

${ }_{18}$ Art. 18, da Lei n 9.307/1996: "O árbitro é juiz de fato e de direito, e a sentença que proferir não fica sujeita a recurso ou a homologação pelo Poder Judiciário".

${ }^{19}$ Art. 134, CF/1988: “Art. 134. A Defensoria Pública é instituição [...] essencial à função jurisdicional do Estado, [...]".
} 


\subsection{Atribuições da advocacia voltadas ao acesso e administração da justiça}

A advocacia, sua organização e a atividade que o representa estão intrinsecamente associadas à justiça, transparente e democrática, vislumbrada pelo constituinte. Esta ideia é confirmada pelas seguintes previsões normativas: i) necessidade de participação da OAB (Ordem dos Advogados do Brasil) em todas as fases de concursos para ingresso na magistratura, ${ }^{20}$ no Ministério Público, ${ }^{21}$ nas procuradorias estaduais e distrital, ${ }^{22}$ e na Defensoria Pública; ${ }^{23}$ ii) hipótese legal de limitação da presença no julgamento de certas decisões judiciais somente a advogados ${ }^{24}$ iii) exigência de advogados na composição de tribunais judiciários em todo o Brasil, ${ }^{25}$ com exceção do STF $;{ }^{26}$ legitimidade para propositura

${ }^{20}$ Art. 93, I, da CF/1988: “[...] ingresso na carreira, cujo cargo inicial será o de juiz substituto, mediante concurso público de provas e títulos, com a participação da Ordem dos Advogados do Brasil em todas as fases, [...]".

${ }^{21}$ Art. 129, § 3º da CF/1988: "O ingresso na carreira do Ministério Público far-se-á mediante concurso público [...] assegurada a participação da Ordem dos Advogados do Brasil em sua realização, [...]”.

${ }^{22}$ Art. 132, da CF/1988: "Os Procuradores dos Estados e do Distrito Federal, organizados em carreira, na qual o ingresso dependerá de concurso público de provas e títulos, com a participaçãoda Ordem dos Advogados do Brasil em todas as suas fases, [...]".

${ }^{23}$ Art. 24, da LC n 80/1994: "O ingresso na Carreira da Defensoria Pública da União far-se-á mediante aprovação prévia em concurso público, [...] com a participação da Ordem dos Advogados do Brasil, no cargo inicial de Defensor Público Federal de $2^{\mathrm{a}}$ Categoria". Ver: BRASIL. LC $n^{o}$ 80, de 12 de janeiro de 1994. Organiza a Defensoria Pública da União, do Distrito Federale dos Territórios e prescreve normas gerais para sua organização nos Estados, e dá outras providências. Disponível em: http://www.planalto.gov.br/ccivil_03/leis/lcp/Lcp80.htm. Acesso em: 25 ago. 2017.

Art. 69, da LC n 80/1994: "O ingresso na Carreira da Defensoria Pública do Distrito Federal e dos Territórios farse-á mediante aprovação prévia em concurso público, [...] com a participação da Ordem dos Advogados do Brasil, $[\ldots] "$.

Aplica-se a mesma regra no ingresso às Defensorias Públicas estaduais: art. 112, da LC no 80/1994.

${ }^{24}$ Art. 93, IX, da CF/1988: “[...] todos os julgamentos dos órgãos do Poder Judiciário serão públicos, e fundamentadas todas as decisões, sob pena de nulidade, podendo a lei limitar a presença, em determinados atos, às próprias partes e a seus advogados, ou somente a estes, em casos nos quais a preservação do direito à intimidade do interessado no sigilo não prejudique o interesse público à informação; [...]".

${ }^{25}$ Art. 94, da CF/1988: "Um quinto dos lugares dos Tribunais Regionais Federais, dos Tribunais dos Estados, e do Distrito Federal e Territórios será composto de membros, [...] e de advogados de notório saber jurídico e de reputação ilibada, [...]".

Art. 104, II, da CF/1988: “O Superior Tribunal de Justiça compõe-se de, no mínimo, trinta e três Ministros. [...] um terço, em partes iguais, dentre advogados e membros do Ministério Público Federal, Estadual, do Distrito Federal e Territórios, alternadamente, indicados na forma do art. 94".

Art. 111-A, I, da CF/1988: “O Tribunal Superior do Trabalho compor-se-á de vinte e sete Ministros, [...] sendo: [...] um quinto dentre advogados com mais de dez anos de efetiva atividade profissional [...]".

Art. 119, II, da CF/1988: "O Tribunal Superior Eleitoral compor-se-á, no mínimo, de sete membros, escolhidos: [...] por nomeação do Presidente da República, dois juízes dentre seis advogados de notável saber jurídico e idoneidade moral, indicados pelo Supremo Tribunal Federal".

Art. 123, parágrafo único, I, da CF/1988: “O Superior Tribunal Militar compor-se-á de quinze Ministros vitalícios, nomeados pelo Presidente da República, depois de aprovada a indicação pelo Senado Federal, sendo [...], e cinco dentre civis. Parágrafo único. Os Ministros civis serão escolhidos pelo Presidente da República dentre brasileiros maiores de trinta e cinco anos, sendo: [...] três dentre advogados de notório saber jurídico e conduta ilibada, com mais de dez anos de efetiva atividade profissional; [...]".

${ }^{26}$ Art. 101, da CF/1988: "O Supremo Tribunal Federal compõe-se de onze Ministros, escolhidos dentre cidadãos com mais de trinta e cinco e menos de sessenta e cinco anos de idade, de notável saber jurídico e reputação ilibada". 
de ADI (Ação Direta de Inconstitucionalidade) e ADC (Ação Declaratória de Constitucionalidade) à $\mathrm{OAB} ;{ }^{27}$ iv) participação na composição do CNJ (Conselho Nacional de Justiça) $^{28}$ e do CNMP (Conselho Nacional do Ministério Público); ${ }^{29}$ v) reconhecimento de indispensabilidade à administração da justiça e vi) inexistência de subordinação entre advogados, magistrados e representantes do Ministério Público, ${ }^{30}$ além da natureza de interesse público de seus serviços. ${ }^{31}$

Observa-se que a "bagagem" advocatícia, por assim dizer, faz parte da maioria absoluta do número de órgãos da estrutura judiciária brasileira (fonte formal de justiça por excelência), inclusive na função de autocontrole, representada pelo CNJ. Via assemelhado raciocínio, observa-se que a representação da advocacia strictu sensu ${ }^{32}$ também exemplifica sua importância como instituição fiscalizatória das demais funções essenciais à justiça (Ministério Público, Advocacia Pública e Defensoria Pública), destacadamente quando da exigência de participação da $\mathrm{OAB}$ no processo de admissão de seus membros.

A exposição dos exemplos de atuação da estrutura advocatícia no interior da administração estatal, inclusive com viés fiscalizatório e aferidor da qualidade do serviço público, não parece apenas demonstrar o alto nível de influência político-institucional que a advocacia exerce. Corrobora, sobretudo, com o reconhecimento da importância da função

27 Art. 103, VII, da CF/1988: "Podem propor a ação direta de inconstitucionalidade e a ação declaratória de constitucionalidade: [...] o Conselho Federal da Ordem dos Advogados do Brasil; [...]"

${ }^{28}$ Art. 103-B, XII, da CF/1988: "OConselho Nacional de Justiça compõe-se de 15 (quinze) membros com mandato de 2 (dois) anos, admitida 1 (uma) recondução, sendo: [...] dois advogados, indicados pelo Conselho Federal da Ordem dos Advogados do Brasil; [...]"

${ }^{29}$ Art. 130-A, V, da CF/1988: "O Conselho Nacional do Ministério Público compõe-se de quatorze membros nomeados pelo Presidente da República, depois de aprovada a escolha pela maioria absoluta do Senado Federal, para um mandato de dois anos, admitida uma recondução, sendo: [...] dois advogados, indicados pelo Conselho Federal da Ordem dos Advogados do Brasil; [...]".

${ }^{30}$ Art. $6^{\circ}$, da Lei n ${ }^{\circ}$ 8.906/1994(Lei Nacional): "Não há hierarquianem subordinação entre advogados, magistrados e membros do Ministério Público, devendo todos tratar-se com consideração e respeito recíprocos".

31 Art. 44, I, Lei $n^{\circ}$ 8.906/1994: “A Ordem dos Advogados do Brasil (OAB), serviço público, dotada de personalidade jurídica e forma federativa, tem por finalidade: [...] defender a Constituição, a ordem jurídica do Estado democrático de direito, os direitos humanos, a justiça social, e pugnar pela boa aplicação das leis, pela rápida administração da justiça e pelo aperfeiçoamento da cultura e das instituições jurídicas; [...]”.

Ressalte-se que "[...] Justiça socialé a virtude que incumbe aos indivíduos e aos grupos, e os obriga aos atos mais conducentes ao maior bem comum" Cf.: ÁVILA, Fernando Bastos de. Neocapitalismo, socialismo, solidarismo. Rio de Janeiro: Agir, 1964.

Art. $2^{\circ}$, $\S 1^{\circ}$ e $2^{\circ}$, da Lei $n^{\circ} 8.906 / 1994:$ “[...] no seu ministério privado, o advogado presta serviço público e exerce função social. No processo judicial, o advogado contribui, na postulação de decisão favorável ao seu constituinte, ao convencimento do julgador, e seus atos constituem múnus público".

${ }^{32}$ Art. $3^{\circ}, \S 1^{\circ}$, da Lei n ${ }^{\circ} 8.906 / 1994:$ "Exercem atividade de advocacia, sujeitando-se ao regime desta lei, além do regime próprio a que se subordinem, os integrantes da Advocacia-Geral da União, da Procuradoria da Fazenda Nacional, da Defensoria Pública e das Procuradorias e Consultorias Jurídicas dos Estados, do Distrito Federal, dos Municípios e das respectivas entidades de administração indireta e fundacional”. 
advocacia no processo de alcance e permanente construção dos objetivos da República Federativa do Brasil, entre os quais liberdade, democracia e justiça. Constrói-se e aperfeiçoase uma sociedade livre, justa e democrática mediante transparência das atividades públicas, possibilitando que os interessados influenciem na formação das decisões estatais.

Independentemente do que mencionado, poder-se-ia erroneamente interpretar que a indispensabilidade prevista no art. 133 da CF/1988 refere-se à função advocacia e não ao advogado. Porém, se assim fosse, o constituinte não teria diferenciado advocacia de advogado em várias passagens do texto constitucional, conferindo àquela o atributo de "essencial" e a este, o de "indispensável”. Além do mais, no interior de processos, incontestavelmente não é a advocacia, mas o advogado (art. $3^{\circ}, \S 1^{\circ}$, da Lei $\left.n^{\circ} 8.906 / 1994\right)$ o porta-voz direto, em regra, dos interesses em discussão.

\section{ATUAÇÃO DO ADVOGAdO EM PROCESSOS: EXPRESSÃO DO DEVIDO PROCESSO LEGAL SUBSTANCIAL}

A garantia do devido processo legal substancial envolve conjuntamente o direito de pedir, ${ }^{33}$ negar e de amplamente defender (ideias, interpretações e argumentos), além da obtenção de respostas num cenário de transparência e efetiva participação (não apenas formal) ${ }^{34}$ através, inclusive, da real disponibilidade de todos os meios e recursos formais e materiais juridicamente permitidos.

\subsection{Implicações da garantia do devido processo legal substancial}

\footnotetext{
${ }^{33}$ Art. 5, XXXIV, “a”, da CF/1988: "são a todos assegurados, [...] o direito de petição aos Poderes Públicos em defesa de direitos ou contra ilegalidade ou abuso de poder; [...]".

${ }^{34}$ Segundo Reuder Rodrigues, o devido processo legal substancial impõe a efetiva observância da CF/88 e de seus fundamentais valores, indo além da mera formalidade. Trata-se da superação do caráter simplesmente formal, dando efetividade ao rol de garantias dos cidadãos em face de qualquer autoridade pública. Ver: ALMEIDA, Reuder Rodrigues Madureira de. Devido processo legal: observância do contraditório e da ampla defesa nos processos administrativos de controle. Revista TCEMG. Comentando a jurisprudência. Belo Horizonte, p. $127-$ 144, out./nov./dez., 2013.
} 
A justiça alusiva às "funções essenciais" constitucionalmente prevista diz respeito à capacidade de extrair da ordem jurídica solução concreta, além de eficaz e eficiente quanto ao cumprimento das diretrizes e objetivos da República Federativa do Brasil, ${ }^{35}$ sejam quais forem, sem que haja o comprometimento de direitos fundamentais. Em virtude das diversas fontes normativas na estrutura estatal brasileira, a administração da justiça ocorre no interior de toda a Administração, independente dos Poderes, o que requer destes a materialização de práticas dirigidas e adequadas à finalidade justiça. Promover e aperfeiçoar a justiça exigem mecanismos procedimentais, meios e recursos efetivamente capazes, entre os quais, o devido processo legal e a função advocatícia latu sensu. ${ }^{36}$

A garantia ao devido processo legal substancial encontra-se no rol dos direitos individuais, constituindo cláusula pétrea, ${ }^{37}$ e se reveste - para sua efetiva implementação - de vários outros direitos, entre os quais: i) pedir e obter resposta; ${ }^{38}$ ii) juiz natural; iii) presunção de inocência; ${ }^{39}$ iv) contraditório; v) ampla defesa e recursos a ela inerentes; vi) publicidade; ${ }^{40}$ vii) decisão fundamentada; viii) impugnação; ix) prova lícita; ${ }^{41}$ x) razoável duração do processo; ${ }^{42} \mathrm{xi}$ ) direito de não fazer prova contra si. ${ }^{43}$

Os corolários da garantia ao devido processo legal substancial indicam a amplitude não só da garantia constitucional referida, mas, por razões lógicas, do direito de acesso a ela.

\footnotetext{
${ }^{35}$ Destacadamente, os incisos II e III do art. $1^{\circ}$, da CF/1988: “Art. $1^{\circ}$ A República Federativa do Brasil, formada pela união indissolúvel dos Estados e Municípios e do Distrito Federal, constitui-se em Estado Democrático de Direito e tem como fundamentos: "[...] a cidadania e [...] dignidade da pessoa humana; [...]".

${ }^{36}$ Os meios e recursos referidos não se encontram escalonados entre si, pois se implicam reciprocamente. Entre eles há várias intercessões, independentemente de sua natureza formal ou material.

${ }^{37}$ Art. 60, $\S 4^{\circ}$, IV, da CF/1988: "não será objeto de deliberação a proposta de emenda tendente a abolir: [...] os direitos e garantias individuais".

38 Art. 5, XXXIV, "a", da CF/1988.

Quanto ao direito de ser respondido, veja-se o art. 48, da Lei n ${ }^{\circ}$ 9.784/1999, por exemplo: “A Administração tem o dever de explicitamente emitir decisão nos processos administrativos e sobre solicitações ou reclamações, em matéria de sua competência". Ver: BRASIL. Lei $n^{\circ}$ 9.784, de 29 de janeiro de 1999. Regula o processo administrativo no âmbito da Administração Pública Federal. Disponível em: http://www.planalto.gov.br/ccivil_03/leis/L9784.htm. Acesso em: 25 ago. 2017.

39 Art. 50, LVII, da CF/1988: "ninguém será considerado culpado até o trânsito em julgado de sentença penal condenatória;".

${ }^{40}$ Art. 50, LX, da CF/1988: "a lei só poderá restringir a publicidade dos atos processuais quando a defesa da intimidade ou o interesse social o exigirem;".

${ }^{41}$ Art. 5, LVI, da CF/1988: "são inadmissíveis, no processo, as provas obtidas por meios ilícitos;".

${ }^{42}$ Art. $5^{\circ}$, LXXVIII, da CF/1988: "a todos, no âmbito judicial e administrativo, são assegurados a razoável duração do processo e os meios que garantam a celeridade de sua tramitação".

${ }^{4} 3$ O Pacto de São José da Costa Rica, incorporada ao ordenamento jurídico brasileiro pelo Decreto no 678/1992, prevê garantias mínimas a serem asseguradas no processo judicial, entre as quais: juiz natural, direito de recorrer e de não fazer prova contra si mesmo. Ver: BRASIL. Decreto 678, de 6 de novembro de 1992. Promulga a Convenção Americana sobre Direitos Humanos (Pacto de São José da Costa Rica), de 22 de novembro de 1969. Disponível em: http://www.planalto.gov.br/ccivil_03/decreto/d0678.htm. Acesso em: 29 ago. 2017.
} 
Vinculam os intérpretes e operadores do Direito em geral quanto ao genérico dever de exercitar a real democracia em quaisquer procedimentos processuais, independentemente da origem destes. Sendo assim, justiça necessariamente decorre, quanto à sua formação e aperfeiçoamento, do devido processo legal substancial. ${ }^{44}$ Ausente ampla defesa, pois, inexiste devido processo legal substancial, o que exclui a possibilidade de decisões justas no sentido aqui adotado.

Todas as garantias e direitos atrelados ao devido processo legal substancial devem refletir sua natureza. Por conseguinte, ampla defesa não mais se identifica apenas pela igualdade meramente formal de igualdade de tratamento no processo. ${ }^{45}$ Arranjo democrático é inerente à defesa ampla com viés material, indo além da mera formalidade, para garantir amplo e efetivo acesso às fontes de justiça, independentemente da natureza do meio e recurso a ela inerentes. Aludi à defesa de interpretações, pontos de vista, ideias, juízos e de opiniões tanto das partes como dos demais interessados, como meios imediatos de influência na elaboração da norma, a exigir não só o direito, mas o dever de colaboração no processo. ${ }^{46}$ Ampla defesa, pois, referese ao implemento de meios e recursos à tutela dos mais diversos direitos, ainda que estes apenas se suponham titularizar (em vista a possibilidade de posterior sucumbência processual).

Por conseguinte, argumenta-se que o direito à ampla defesa substancial deve ser interpretado de maneira a abranger não apenas litigantes e acusados em geral, já que não apenas eles detêm o direito de expor argumentos e demonstrar fatos nos limites do processo. A título exemplificativo, a depender da matéria e do procedimento processual implementado, exposição e prova podem interessar ao Ministério Público (ainda que somente como fiscal da lei),

\footnotetext{
${ }^{44}$ Luís Roberto Barroso, apregoa que a razoabilidade atrelada ao princípio do devido processo legal material ou substancial significa a "[...] compatibilidade entre o meio empregado pelo legi slador e os fins visados, bem como a aferição da legitimidade dos fins". Ver: BARROSO, Luís Roberto. Interpretação e aplicação da Constituição. Fundamentos de uma dogmática constitucional transformadora. São Paulo: Saraiva, 1996.

${ }^{45}$ Entre os intérpretes das normas constitucionais, encontra-se o legislador infraconstitucional. Face a isso, também é ele destinatário dos princípios de interpretação constitucional como o da efetividade ou eficiência. Desta forma, deve exercer sua competência com base também em balizadas interpretativas do texto constitucional.

${ }^{46}$ Art. 378, da Lei no 13.105/2015: "Ninguém se exime do dever de colaborar com o Poder Judiciário para o descobrimento da verdade". Ver: BRASIL. Lei $n^{\circ} 13.105$, de 16 de março de 2015. Código de Processo Civil. Disponível em: http://www.planalto.gov.br/ccivil_03/_ato2015-2018/2015/lei/113105.htm. Acesso em: 29 ago. 2017.

Porém, a depender da matéria discutida no processo, excepciona-se o dever mencionado: ao réu no processo penal lhe concede, ao contrário, o direito de permanecer calado e de não responder a perguntas que lhe forem formuladas (art. 186, do Decreto-lei n ${ }^{\circ} 3.689 / 1941$ ). Ver: BRASIL. Decreto-Lei $n^{\circ} 3.689$, de 3 de outubro de 1941. Código de Processo Penal. Disponível em: http://www.planalto.gov.br/ccivil_03/decreto-lei/Del3689.htm. Acesso em: 29 ago. 2017.
} 
assistente da acusação, amicus curie e a titular de um interesse material qualquer, como nos casos da jurisdição voluntária, por exemplo.

Os envolvidos no processo, por vezes, são factualmente desiguais. Em vista disso, a proposta de igualação do devido processo legal substancial envolve tratamento desigual, a fim de reduzir ao mínimo possível o eventual desequilíbrio original entre os envolvidos no processo. ${ }^{47}$ Objetiva-se criar, aplicar e tutelar meios e recursos variados, juridicamente permitidos, capazes de, adequadamente, maximizar e aperfeiçoar o acesso às fontes imediatas e indiretas de justiça, o que exige participação e colaboração num ambiente democrático.

\subsection{Atuação do advogado em processos: materialidade da ampla defesa}

Como ninguém deve ser privado da liberdade e de seus bens sem o devido processo legal substancial, a garantia da ampla defesa implica expandir o direito de acesso, de participação e de atuação, de maneira equitativa em relação às partes e interessados no processo, sendo este de origem estatal ou não, sob pena de comprometimento da justa decisão. Quaisquer meios e recursos juridicamente disponíveis, dirigidos à concepção, desenvolvimento e aperfeiçoamento de normas justas, devem ser viabilizados pelo Estado aos aplicadores da lei e aos interessados.

Quanto a recursos humanos, presume-se que apenas profissionais especializados ${ }^{48}$ podem, a contento, fazer a defesa de pontos de vista, ideias, juízos e opiniões no interior do processo e naquilo que lhe é pertinente, visto que as diversas interpretações são os meios por excelência de influência na criação normativa. ${ }^{49}$ A propósito: “[...] O exercício do poder-dever de questionar, de fiscalizar, de criticar e de buscar a correção de abusos cometidos por órgãos

\footnotetext{
${ }^{47}$ Corresponde ao propósito de igualdade como valor político e jurídico a orientar não apenas a elaboração de normas, mas inclusive de políticas públicas.

48 Apenas para ilustrar, vale citar o art. $4^{\circ}$, da Lei $\mathrm{n}^{\circ}$ 8.906/1994: "São nulos os atos privativos de advogado praticados por pessoa não inscrita na $\mathrm{OAB}$, sem prejuízo das sanções civis, penais e administrativas. Parágrafo único. São também nulos os atos praticados por advogado impedido - no âmbito do impedimento - suspenso, licenciado ou que passar a exercer atividade incompatível com a advocacia".

${ }^{49}$ Art. $2^{\circ}$, $\S 2^{\circ}$, da Lei ${ }^{\circ}$ 8.906/1994: "No processo judicial, o advogado contribui, na postulação de decisão favorável ao seu constituinte, ao convencimento do julgador, e seus atos constituem múnus público". Ressalte-se que, independentemente do processo e de sua origem, as contribuições expostas são as mesmas.

Testemunhos, declarações e interrogatórios, conforme o caso, manifestadas por leigos, conquanto devam influenciar o tomador de decisões, não excepcionam a regra que exige a participação de técnicos especializados no processo, face à sua natureza e à lógica funcional que as envolve.
} 
públicos e por agentes e autoridades do Estado, inclusive magistrados, reflete prerrogativa indisponível do advogado, $[\ldots]$... ${ }^{50}$

Magistrados, promotores públicos, defensores públicos, procuradores públicos e advogados. ${ }^{51}$ Conquanto todos eles possam ser assessorados por profissionais aptos à realização de tarefas como confecção de decisões, votos, minutas, pareceres, requerimentos e defesas, a imprescindibilidade daqueles indica que não basta qualificação técnica, tendo em vista que seus auxiliares a tem. Necessários, conforme o caso, investidura no cargo/emprego e/ou registro nos órgãos de controle e fiscalização competentes. ${ }^{52}$ Os requisitos referidos não revelam formalidades vazias de sentido. Existem, basicamente, por duas razões: i) como elementos objetivos de verificação e aferição da responsabilidade do profissional, agente público ou não, quanto à correspondência entre sua conduta e as atividades para as quais se presume preparado ${ }^{53}$ ii) como promoção de recursos e meios aptos, além de juridicamente seguros, a garantir efetividade aos direitos fundamentais num ambiente de ampla e irrestrita promoção e aprimoramento da justiça.

Repise-se que a indispensabilidade do advogado à administração da justiça é regra geral, haja vista o tratamento que o constituinte dá à atividade advocatícia e, em específico, ao advogado. A valoração da estrutura funcional da atividade se dá, entre outros, mediante a necessidade de verificação de mínima capacidade técnica dos bacharéis interessados ao exercício da atividade de advogado. Com isso, não há intensão de permitir, a rigor, restrição aos direitos de assistência por advogado e ao livre exercício de qualquer trabalho. Na realidade, o atendimento à qualificação profissional vai ao encontro dos interesses de seus regulares

\footnotetext{
${ }^{50}$ BRASIL. Supremo Tribunal Federal. HC 98.237/SP. $2^{\text {a }}$ Turma. Rel. Min. Celso de Mello, Brasília, DJ 6 ago. 2010.

${ }^{51}$ À exceção,por óbvio, dos membros do Poder Judiciário e dos agentes do Ministério Público, "Exercem atividade de advocacia, sujeitando-se ao regime desta lei, além do regime próprio a que se subordinem, os integrantes da Advocacia-Geral da União, da Procuradoria da Fazenda Nacional, da Defensoria Pública e das Procuradorias e Consultorias Jurídicas dos Estados, do Distrito Federal, dos Municípios e das respectivas entidades de administração indireta e fundacional", (art. $3^{\circ}, \S 1^{\circ}$, da Lei n $\left.{ }^{\circ} 8.906 / 1994\right)$.

52 Art. $3^{\circ}$, da Lei $n^{\circ}$ 8.906/1994: "O exercício da atividade de advocacia no território brasileiro e a denominação de advogado são privativos dos inscritos na Ordem dos Advogados do Brasil(OAB);”.

${ }^{53}$ Para o exercício da atividade advocatícia latu sensu exige-se o cumprimento prévio de uma série de requisitos legais. Assim, não parece nem mesmo razoável exigir "dever de cuidado" profissional daquele que sabidamente não é formalmente habilitado a exercer defesa técnica em processos, atividade para a qual compulsoriamente the fora designada.
} 
prestadores e dos usuários dos serviços,${ }^{54}$ mediante fiscalização e controle da atividade e dos que atuam, com possibilidade de sanção aos infratores. ${ }^{55}$

A garantia da ampla defesa e a indispensabilidade de advogado devem ser lidas em conjunto. O direito à defesa técnico-jurídica, presumidamente prestada somente por profissional formalmente habilitado, é compreendida pela garantia da defesa ampla. Tem o legislador infraconstitucional o dever-poder de implementar mecanismos para garantir sua efetivação, sob pena de violação constitucional. Nada obstante, não há direitos absolutos, ${ }^{56}$ podendo o legislador, excepcionalmente, prever situações em que a assistência técnica de advogado em processo é prescindível, a exigir o cumprimento simultâneo de certas formalidades: i) vedação de "exigência" de dispensa de assistência técnico-jurídica por profissional habilitado, permitindo-se apenas sua "autorização"; ii) autorização de dispensa unicamente em situações em que, impreterivelmente, beneficia-se diretamente o titular do direito à ampla defesa.

Não só o intérprete tem poder limitado, o legislador infraconstitucional também. Por isso, a autorização de dispensa, além de cumprir as formalidades imediatamente supra referidas, deve embasar-se na técnica da ponderação dos interesses do titular do direito à ampla defesa. ${ }^{57}$ Tratam-se de situações excepcionais em que se relativizam direitos constitucionais, por não ser possível desprezar completamente um direito em nome da aplicação de outro de mesma estirpe. Trazem-se à baila, a título exemplificativo, as seguintes previsões legais nas quais se autoriza a dispensa de assistência técnico-jurídica por advogado em benefício do titular do direito à defesa ampla, para o fim, por outro lado, de ampliação do direito de acesso à justiça: i) art. 791

\footnotetext{
54 À semelhança das prerrogativas dos membros do Judiciário e do Ministério Público, tão necessárias ao livre exercício de suas competências e atribuições, atribuem-se aos profissionais da advocacia legalmente habilitados prerrogativas consideradas imprescindíveis ao adequado exercício de seu ofício: arts. $6^{\circ}$ e $7^{\circ}$ da Lei no ${ }^{\circ}$ 8.906/1994. 55 Trata-se, pois, de norma constitucional de aplicabilidade imediata, porém passível de específicas contenções, a exemplo da escolha de como e por que meios, conforme o caso, o direito à liberdade profissional poderá ser exercido.

${ }^{56}$ BRASIL. Supremo Tribunal Federal. RvC 4886/SP, Tribunal Pleno. Rel. Min. Sepúlveda Pertence. Brasília, DJ 23 abril 1993.

57 A propósito do tema, a espécie de técnica interpretativa da constituição intitulada concordância prática ou harmonização cuida do implemento da coordenação e articulação de bens jurídicos constitucionais, inclusive quando entram em conflito entre si. (grifos nossos). Ver: HESSE, Konrad. A Força Normativa da Constituição. Tradução de Gilmar Ferreira Mendes. Porto Alegre: Sérgio Antônio Fabris, 1991.
} 
e $\S 2^{\circ}$, do Decreto-Lei ${ }^{\circ} 5.452 / 1943 ;{ }^{58}$ ii) art. $9^{\circ}$, da Lei $n^{\circ} 9.099 / 1995 ;{ }^{59}$ iii) art. 10, da Lei ${ }^{\circ}$ $10.259 / 2001 ;{ }^{60}$ iv) arts. $1^{\text {o }}$ c/c $3^{\circ}$, IV, da Lei $n^{\circ} 9.784 / 1999 ;{ }^{61}$ v) art. 156 , da Lei 8.112/1990; ${ }^{62}$ arts. 623 e 654, do Decreto-Lei no $3.689 / 1941 .^{63}$

\section{ANÁlISE dA PREVISÃo de ATUAÇÃo DE DEFENSOR DATIVO NÃO ADVOGADO EM PROCESSO ADMINISTRATIVO DISCIPLINAR SOB O PRISMA CONCEITUAL DA JUSTIÇA}

A atuação de profissional tecnicamente habilitado na defesa de envolvidos em processo judicial ou administrativo manifesta obediência ao direito ao emprego de todos os "meios e recursos" inerentes à ampla defesa. Com essa premissa, avalia-se o conteúdo do art. $164, \S 2^{\circ}$, da Lei $n^{\circ} 8.112 / 1990$ e a norma presente na Súmula Vinculante $n^{\circ} 5$.

\subsection{Defesa técnico-jurídica: atribuição de profissional habilitado}

\footnotetext{
58 Art. 791, do Decreto-Lei no 5.452/1943: “Os empregados e os empregadores poderão reclamar pes soalmente perante a Justiça do Trabalho e acompanhar as suas reclamações até o final. [...] § $2^{\circ}$ - Nos dissídios coletivos é facultada aos interessados a assistência por advogado". Ver: BRASIL. Decreto-Lein ${ }^{\circ}$ 5.452, de 1 de maio de 1943. Aprova a Consolidação das Leis do Trabalho. Disponível em: http://www.planalto.gov.br/ccivil_03/decretolei/Del5452.htm. Acesso em: 29 ago. 2017.

59 Art. $9^{\circ}$, da Lei n 9.099/1995: “Art. $9^{\circ}$ Nas causas de valor até vinte salários mínimos, as partes comparecerão pessoalmente, podendo ser assistidas por advogado; [...]”. Ver: BRASIL. Lei n ${ }^{\circ}$ 9.099, de 26 de setembro de 1995. Dispõe sobre os Juizados Especiais Cíveis e Criminais e dá outras providências. Disponível em: http://www.planalto.gov.br/ccivil_03/leis/L9099.htm. Acesso em: 28 ago. 2017.

${ }^{60}$ Art. 10, da Lei n ${ }^{\circ}$ 10.259/2001: “As partes poderão designar, por escrito, representantes para a causa, advogado ou não". Ver: BRASIL. Lei $n^{\circ} 10.259$, de 12 e julho de 2001. Dispõe sobre a instituição dos Juizados Especiais Cíveis e Criminais no âmbito da Justiça Federal. Disponível em: http://www.planalto.gov.br/ccivil_03/leis/LEIS_2001/L10259.htm. Acesso em: 25 ago. 2017.

61 Art. 3, IV, da Lei n ${ }^{\circ}$ 9.784/1999: "O administrado tem os seguintes direitos perante a Administração, sem prejuízo de outros que lhe sejam assegurados: [...] fazer-se assistir, facultativamente, por advogado, salvo quando obrigatória a representação, por força de lei".

62 Art. 156, da Lei n ${ }^{\circ} 8.112 / 1990$ : “É assegurado ao servidor o direito de acompanhar o processo pessoalmente ou por intermédiode procurador, arrolar e reinquirir testemunhas, produzir provas e contraprovas e formular quesitos, quando se tratar de prova pericial".

63 Art. 623, do Código de Processo Penal: “A revisão poderá ser pedida pelo próprio réu ou por procurador legalmente habilitado ou, no caso de morte do réu, pelo cônjuge, ascendente, descendente ou irmão".

Art. 654, do Código de Processo Penal: “O habeas corpus poderá ser impetrado por qualquer pessoa, em seu favor ou de outrem, bem como pelo Ministério Público".
} 
A possibilidade de nomeação de um não advogado como defensor dativo em processo administrativo disciplinar (art. 164, $\S 2^{\circ}$, da Lei $n^{\circ} 8.112 / 1990$ ) sem visar a benefícios ao processado conflita com a garantia da defesa ampla, da qual decorre o direito à defesa técnicojurídica. A constitucionalmente válida dispensa de advogado (o que inclui advogado dativo) pelo poder público ao titular do direito à ampla defesa é aquela em que o legislador infraconstitucional não a determina, apenas a autoriza, e exclusivamente para maiores benefícios aos titulares de direitos fundamentais. A previsão de designação de "defensor dativo" ao administrativamente processado implica, por si só, reconhecimento do direito de defesa; contudo, paradoxalmente, ao permiti-la por profissional não habilitado sem que haja benefícios compensatórios, viola-se a ampla defesa, desobedecendo o devido processo legal substancial.

A ausência de apresentação de defesa no prazo legal do indiciado, ${ }^{64}$ por exemplo, justifica resposta estatal; todavia, o feedback não deve ser antidemocrático. Permitir defesa não técnica sem visar a benefícios ao servidor-administrado (in casu), é infringir o dever estatal de garantir defesa ampla, violando o devido processo legal, medida incompatível com processo por meio do qual as partes têm minimizadas suas reais diferenças. ${ }^{65}$ A previsão legal em apreço (art. 164, $\S 2^{\circ}$, da Lei $n^{\circ} 8.112 / 90$ ) não indica apenas prejuízo a direito subjetivo do servidoradministrado, mas claro retrocesso à proposta de cumprimento das diretrizes e objetivos da República Federativa do Brasil.

De maneira geral, a defesa técnico-jurídica apenas se deve aguardar de advogado, seja profissional liberal (dativo ou não) ou agente do poder público (procuradores e defensores públicos). Trata-se de presunção, em vista da qualificação formal e da específica aferição, pela $\mathrm{OAB}$ ou por outros meios correspondentes legalmente reconhecidos. ${ }^{66}$ Em certa medida, a possibilidade de nomeação como defensor dativo de um não advogado faz presumir que qualquer profissional, independe da área de atuação, pode em tese suprir o profissional da atividade advocatícia em seu ofício. Considerando-o válido, o $§ 2^{\circ}$ do art. 164 da Lei ${ }^{\circ}$

\footnotetext{
${ }^{64}$ Art. 164, da Lei no 8.112/1990: “Considerar-se-á revel o indiciado que, regularmente citado, não apresentar defesa no prazo legal".

${ }^{65}$ Segundo lições de Antônio Joaquim Ribas, "Quanto mais democrática fosse a época, o processo administrativo deixava de ter um caráter punitivo dos servidores da administração, para ser um instrumento protetivo dos administrados, reduzindo o arbítrio da autoridade, limitando seu poder". Ver: RIBAS, Antônio Joaquim. Direito Administrativo Brasileiro. Noções preliminares. Rio de Janeiro: F. L. Pinto e C, Livreiros-editores, 1866.

${ }^{66}$ Nomeação para cargo efetivo ou em comissão, desde que para cargo ou emprego de advogado, consoante a Lei $\mathrm{n}^{\mathrm{o}} 8.906 / 1994$.
} 
$8.112 / 1990$, leva a crer que quaisquer profissionais podem tornar efetiva a garantia da defesa ampla, a qual compreende necessariamente a defesa técnico-jurídica.

Situações em que, hipoteticamente, a qualidade do serviço advocatício executado por profissional habilitado comprometa o direito de efetiva defesa, corresponde ao que se denomina cerceamento de defesa,${ }^{67}$ podendo levar inclusive à anulação de atos processuais. ${ }^{68}$ Diante dessa possibilidade, maior razão há para o não reconhecimento de validade de atos decorrentes de defesa processual realizada por não profissional ou por profissional não habilitado no ofício advocatício.

Hipoteticamente, é possível que pessoa não habilitada possa apresentar defesa técnicojurídica com nível de qualidade superior ao que se espera do resultado do trabalho de certos advogados. Entretanto, não é esta a regra, visto que não se espera do não habilitado a capacidade técnica aguardada do formalmente apto. A presunção, quando das ausências de qualificação formal e, por conseguinte, da aferição da aptidão técnica por entidade de fiscalização e controle, é de insuficiência de defesa técnica ou de sua total carência quando promovida por não habilitado. Daí a existência de tutela jurídica tanto do profissional como do tomador dos serviços. ${ }^{69}$ Observa-se que a contratação de profissionais habilitados para a execução de serviços, seja o contrato gerador de obrigação de meio ou de resultado, baseia-se na presunção de que o serviço a ser prestado seja a contento justamente por conta da qualificação formal do profissional, aliada, por vezes, à experiência profissional.

\footnotetext{
${ }^{67}$ Leciona Humberto Theodoro Júnior: “Quando se afirma o caráter absoluto do princípio do contraditório, o que se pretende dizeré que nenhum processo ou procedimento pode ser disciplinado sem assegurar às partes a regra de isonomia no exercício das faculdades processuais. [...] Não pode o juiz conduzir o processo se $m$ respeitar o contraditório; à parte, entretanto, cabe a liberdade de exercitá-lo ou não, segundo seu puro alvedrio. Ninguémé obrigado a defender-se. O direito de participar do contraditórioé, nessa ordem, disponível. Logo, mesmo quando o juiz o desobedece, cometendo cerceamento de defesa, o processo ficará passível de nulidade". Ver: THEODORO JÚNIOR, Humberto. Curso de Direito Processual Civil - Teoria geral do direito processual civil e processo de conhecimento - vol. I. Rio de Janeiro: Forense, 2014.

${ }^{68}$ BRASIL. STF. Súmula 523 - "No processo penal, a falta da defesa constitui nulidade absoluta, mas a sua deficiência só o anulará se houver prova de prejuizo para o réu”. Tribunal Pleno. Brasília, DJ 10 dez.1969.

Independentemente de a Súmula referir-se expressamente aos processos penais, seu conteúdo aplica-se a todo e qualquer processo judicial.

A completa ausência de defesa configura presunção absoluta de prejuízo à parte, ensejando a nulidade absoluta. No caso de apenas deficiência da defesa, paira presunção relativa de prejuízo, levando à anulação somente se a deficiência for confirmada e na medida do prejuízo constatado.

Finalmente, toda a análise baseia-se no cumprimento ou não da finalidade insculpida no enunciado que prevê a ampla defesa.

${ }^{69}$ Art. $5^{\circ}, \mathrm{XIII}, \mathrm{da} \mathrm{CF} / 1988$ : “élivre o exercício de qualquer trabalho, ofício ouprofissão, atendidas as qualificações profissionais que a lei estabelecer".
} 
Com base no que exposto, a determinação de não habilitado para realizar defesa técnicojurídica em processo administrativo disciplinar, incompatibiliza-se com valores democráticos, viola a garantia do devido processo legal substancial, a ampla defesa, o livre exercício de qualquer trabalho, além do direito a que o poder público em geral faça escolhas proporcionais. ${ }^{70}$

\subsection{O injusto conteúdo normativo da Súmula Vinculante $n^{0} 5$ : análise do $\operatorname{art.164,~} 2^{\circ}$, da}

\section{Lei $\mathbf{n}^{0} 8.112 / 1990$}

No contexto da democracia moderna, a dimensão material da justiça fundamenta-se na ideia de que cada indivíduo titularize direitos mínimos e que, em resposta às desigualdades humanas naturais, caiba ao Estado promover oportunidades àqueles que delas necessitam para o exercício daqueles direitos. No cenário dos deveres jurídico-políticos estatais, estes axiomas complementam-se, semelhantemente pautados tanto pelos fundamentos e objetivos do Estado como pela obediência às garantias fundamentais dos indivíduos .

Para fins deste breve trabalho, justiça não tem como objeto apenas o enunciado jurídico, mas, inclusive, destacadamente a norma que se extrai dele. ${ }^{71}$ Quando da aplicação do enunciado jurídico-normativo, justa é a decisão dirigida, ainda que mediatamente, ao eficiente implemento dos fundamentos e objetivos do Estado, ao mesmo tempo em que não apenas cumpre, mas promova os direitos fundamentais implícitos e explícitos dos indivíduos.

A norma contida no enunciado da Súmula Vinculante $n^{\circ} 5$, por exemplo, apregoa que "A falta de defesa técnica por advogado no processo administrativo disciplinar não ofende a Constituição". Afirma ser inexigível a atuação de advogado regularmente habilitado em processo administrativo, apesar de a lógica da ordem jurídica brasileir a como um todo atribuir apenas ao profissional habilitado - com exclusão de outro profissional, por razões de segurança e controle - a capacidade de adequadamente (pertinência técnico-formal) defender teses, argumentos e ideias técnico-jurídicas.

\footnotetext{
70 OLIVEIRA, José Roberto. Os princípios da razoabilidade e da proporcionalidade no Direito Administrativo brasileiro. In: Coleção Temas de Direito Administrativo 16. São Paulo: Malheiros, 2006.

${ }^{71}$ Para Eros Roberto Grau, norma é a solução do caso concreto, cuja fonte é o enunciado jurídico expresso ou não. Ver: GRAU, Eros Roberto. Ensaio e discurso sobre a interpretaçãolaplicação do Direito. $3^{\mathrm{a}}$ ed. São Paulo: Malheiros, 2005.
} 
Destoando dos paradigmas democráticos constantes na CF/1988, o STF afirma que a carência da atuação de advogado em processo administrativo disciplinar, desde que a mera igualdade formal seja garantida, não viola a ampla defesa, o devido processo legal substancial, o livre exercício de qualquer trabalho e a proporcionalidade. ${ }^{72}$ Porém, no cotidiano do indivíduo comum, titular de direitos e garantias individuais, a mera falta de aplicação da ampla defesa tem efeito prático semelhante à hipotética abolição do mencionado direito. Assegurado ao servidor o direito de ser assistido por defensor técnico-jurídico, conforme preceitua o art. 156 da Lei $n^{\circ}$ 8.112/1990, e havendo o desejo de exercitar tal direito, no mínimo desproporcional a determinação de seguimento de processo administrativo disciplinar sem defesa técnico-jurídica.

Ainda que em localidades em que não há causídico e o servidor não titularize o direito à prestação gratuita de assistência jurídica, ${ }^{73}$ descabe a legalização da impossibilidade do exercício do direito à ampla defesa em todos os seus termos. Não havendo na localidade advogado privado disponível, tanto inexequível a nomeação de advogado dativo pelo Estado; como semelhantemente inviável a contratação de causídico pelo processado. No caso, resta evidente que o titular do direito individual constitucional é "apenado" pelo conteúdo do art. $164, \S 2^{\circ}$, da Lei ${ }^{\circ}$ 8.112/1990, ao ser impossibilitado de exercer o direito de defender-se por profissional habilitado, conquanto por razões fáticas que não deu causa.

A solução dada pelo STF através da Súmula Vinculante $n^{\circ} 5$ não parece adequar-se ao significado de justiça manifestado pela ordem jurídica brasileira. Como visto, a dispensa do direito à defesa técnica, um dos meios e recursos da amplitude da defesa, é disponível somente ao titular da garantia constitucional e em certos casos e ao poder público. ${ }^{74}$ Entretanto, para que o Estado, ainda que por meio de lei, possa dispensá-la validamente, deve fazê-lo somente com a pretensão de beneficiar os titulares do direito à ampla defesa, sob pena de descumprimento da finalidade da garantia constitucional.

${ }^{72}$ BRASIL. Supremo Tribunal Federal. RE 434.059/DF. Tribunal Pleno. Rel. Min. Gilmar Mendes. Brasília, DJ 12 set. 2008.

${ }^{73}$ Art. 5, LXXIV, da CF/1988: “o Estado prestará assistência juríd ica integral e gratuita aos que comprovarem insuficiência de recursos;".

${ }^{74}$ Art. 3, IV, da Lei no 9.784/1999 "O administrado tem os seguintes direitos perante a Administração, sem prejuízo de outros que lhe sejam assegurados: [...] fazer-se assistir, facultativamente, por advogado, salvo quando obrigatória a representação, por força de lei" (grifos nossos). A segunda parte do enunciado trata de situação em que, para beneficiar o administrado, a este não se disponibiliza a possibilidade de dispensa de defesa técnicojurídica. 
Conquanto o art. 156, da Lei $\mathrm{n}^{\circ} 8.112 / 1990$ não exija a dispensa de profissional habilitado - capacitado à promoção de defesa técnico-jurídica - claramente, o art. $164, \S 2^{\circ}$, da referida Lei opera em prejuízo do servidor-administrado, pois em nome unicamente do dever de processar, afasta a exigência de defesa técnico-jurídica por profissional habilitado, afrontando o direito à amplitude de defesa e, por conseguinte, o devido processo legal.

Constata-se a importância do direito à ampla defesa mediante o implemento da defesa técnico-jurídica, face a previsões impeditivas da disponibilidade deste direito até mesmo por seu titular, diretriz geral em todo o ordenamento jurídico brasileiro. Nos processos penais e nos cíveis em geral, por exemplo, entende o legislador que a garantia da ampla defesa só é obedecida quando exercida por profissional técnico-jurídico habilitado. Inclusive em processo administrativo-parlamentar por quebra de decoro parlamentar, o STF entende exigível a defesa por profissional da advocacia, pois "[...] tal como ocorre no processo penal, [...] o acompanhamento dos atos e termos do processo é função ordinária do profissional da advocacia, [...] quando atua no sentido de constituir espécie de defesa técnica" 75 (grifos nossos). Outro exemplo em que se afasta a norma contida na Súmula Vinculante $\mathrm{n}^{\circ} 5$ é o relativo a procedimentos administrativos para apuração de falta grave em estabelecimentos prisionais, ${ }^{76}$ porquanto "[...] tendo em vista estar em jogo a liberdade de ir e vir, deve ser observado amplamente o princípio do contraditório, com presença de advogado constituído ou defensor público nomeado, [...]"77 (grifos nossos).

Vê-se que o STF parece compreender que em dados processos, a ampla defesa não resta violada, ainda que ausente defesa técnico-jurídica por profissional habilitado. Ao mesmo tempo, tendo como referência a mesma garantia constitucional, noutros processos, exige a Suprema Corte a defesa técnico-jurídica por profissional habilitado, sob pena de descumprimento da ampla defesa.

Diante dos posicionamentos distintos para situações equiparadas a respeito da (des) necessidade de atuação de profissional habilitado em processo, conclui-se que o STF parece

\footnotetext{
${ }^{75}$ BRASIL. Supremo Tribunal Federal. MS 25.917/DF, Tribunal Pleno. Rel. Min. Gilmar Mendes, Brasília, DJ 1 set. 2006.

${ }^{76}$ BRASIL. Supremo Tribunal Federal. Rcl 9.340/SP, Tribunal Pleno. Rel. Min. Ricardo Lewandowski, Brasília, DJ 5 set. 2014.

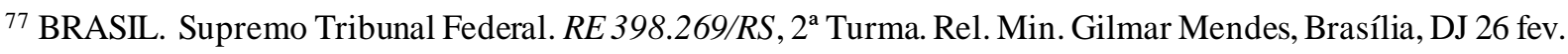
2010 .
} 
adotar mais de uma definição de ampla defesa, a variar de acordo com a matéria processual tratada. O referido arranjo jurídico não se coaduna com as garantias do devido processo legal, ampla defesa e igualdade previstas na $\mathrm{CF} / 1988$, pois o constituinte não permitiu atribuírem-se simultaneamente diferentes sentidos às mesmas garantias, muito menos para permitir a dispensa de modalidades de defesa.

Veja-se que a garantia do devido processo legal pela qual a ampla defesa é envolta, visa indiretamente a tutelar quaisquer bens jurídicos, independentemente de sua natureza ou espécie. Não trazendo benefícios aos titulares dos direitos fundamentais, nem o legislador infraconstitucional, nem o Poder Judiciário podem validamente elaborar critérios, inclusive vinculados à natureza dos bens jurídicos discutidos no processo, tendentes a dispensar a assistência jurídica por profissional habilitado. Ainda que hipoteticamente permitida, a dispensa jamais poderia recair em processo no qual em jogo valores como trabalho, ${ }^{78}$ probidade e eficiência da Administração, ${ }^{79}$ segurança das relações estatais ou quaisquer outros relativos a interesses públicos. ${ }^{80}$

O dogma do interesse público, conceito jurídico indeterminado, não pode mais sustentar condutas estatais, ainda que legais, que não adotem paradigmas verdadeiramente democráticos. ${ }^{81}$ Apesar do dever-poder de o Estado processar em certas situações previstas, inaceitável, exclusivamente em nome da mencionada exigência normativa, tornar inexequíveis garantias fundamentais, esquecendo-se de seus titulares e dos bens jurídicos por elas protegidos, sob pena retrocessão nefasta aos administrados em geral. ${ }^{82}$

\footnotetext{
${ }^{78}$ Art. 5 ${ }^{\circ}$ XIII, da CF/1988; Art. 6º da CF/1988; art. 170, da CF/1988; art. 193, da CF/1988.

79 Art. 37, da CF/1988: “Art. 37. A administração pública direta e indireta de qualquer dos Poderes da União, dos Estados, do Distrito Federal e dos Municípios obedecerá aos princípios de legalidade, impessoalidade, moralidade, publicidade e eficiência [...]".

80 Segundo Miguel Reale, sob o enfoque estritamente procedimental, "As normas representam o momento culminante de um processo que é, essencialmente, inseparável dos fatos que estão em sua origem [...] e dos valores ou fins que constituem a sua razão de ser, assim como dos motivos mediante os quais os valores e fins se atualizam. ". Ver: REALE, Miguel. Estrutura e fundamento da ordem jurídica. Revista de Informação Legislativa. Ano 9, n. 36, p. 245-252, out./dez., 1972.

${ }^{81}$ SUNDFELD, Carlos Ari. Fundamentos de direito público. $4^{\mathrm{a}}$ ed. São Paulo: Malheiros, 2002.

${ }^{82}$ Refere-se ao registro histórico em que o processo administrativo brasileiro tinhacaráter eminentemente punitivo, em contrapartida ao caráter democrático-protetivo do servidor e do administrado em geral. Ver: RIBAS, Antônio Joaquim. Direito Administrativo Brasileiro. Noções preliminares. Rio de Janeiro: F. L. Pinto e C, Livreiroseditores, 1866.
} 


\section{CONCLUSÃO}

O exercício do devido processo legal, admitido como substancializado pela jurisprudência brasileira, é viabilizado por outros direitos, entre os quais, o da defesa ampla. Trata-se, como indica a própria expressão, de defesa qualificada por sua abrangência. Nesse sentido, amplitude indica que a defesa não se destina somente a litigantes e/ou acusados em geral, ao mesmo tempo em que insuficiente a ideia da mera formalidade do direito de defesa.

Ampla defesa substancial destina-se a todos os interessados envolvidos no processo (partes, fiscais, assistentes e terceiros) e se refere à salvaguarda de ideias, interpretações e argumentos. Assim, em função dos destinatários e do objeto da defesa, esta manifesta-se via possibilidade de empregar-se todas as suas modalidades constitucionalmente permitidas, entre as quais a técnico-jurídica, a qual presumidamente realizada a contento apenas por profissional regularmente habilitado.

No cenário exposto, a defesa por profissional habilitado foi confiada às "funções" consideradas essenciais - tais como Ministério Público, Procuradorias Públicas, Defensorias Públicas e a Advocacia em geral - à promoção e aperfeiçoamento da justiça, sem falar, por razões óbvias, do próprio Poder Judiciário. Especificamente quanto à instituição Advocacia, considerada essencial pelo constituinte, ao seu instrumento por excelência, o Advogado, atribui-se a qualidade de indispensável.

Em face das diretrizes constitucionais, não poderia ser diferente, pois é o indivíduo quem dá concretude às funções consideradas de interesse social. Portanto, a presença e atuação de profissional regularmente apto à defesa técnico-jurídica é regra geral, podendo ser excepcionada apenas quando a finalidade da garantia não seja comprometida (núcleo essencial) e somente para fornecer aos indivíduos, não ao Estado, imediatos benefícios decorrentes dos direitos fundamentais.

Partindo-se do conceito de justiça já explicitado, ao analisar o art. 164, $\S 2^{\circ}$, da Lei ${ }^{\circ}$ 8.112/1990 e a norma contida na Súmula Vinculante $\mathrm{n}^{\circ}$ 5, as quais dispensam em certa circunstância a atuação de advogado em processo disciplinar administrativo, verificou-se que, por não garantirem ao servidor-administrado os benefícios que a amplitude da defesa lhe 
reserva, ferem o núcleo essencial da garantia constitucional do devido processo legal substancial, pois descumprem valores como justiça e democracia presentes na CF/1988.

\section{REFERÊNCIAS}

ABBAGNANO, Nicola. Dicionário de Filosofia. Tradução da $1^{a}$ edição brasileira coordenada e revista por Alfredo Bosi; revisão da tradução e tradução dos novos textos por Ivone Castilho Benedetti. $5^{\text {a }}$ ed. revista e ampliada. São Paulo: Martins Fontes, 2007.

ALMEIDA, Reuder Rodrigues Madureira de. Devido processo legal: observância do contraditório e da ampla defesa nos processos administrativos de controle. Revista TCEMG. Comentando a jurisprudência. Belo Horizonte, p. 127-144, out./nov./dez., 2013.

ÁVILA, Fernando Bastos de. Neocapitalismo, socialismo, solidarismo. Rio de Janeiro: Agir, 1964.

BARROSO, Luís Roberto. Interpretação e aplicação da Constituição. Fundamentos de uma dogmática constitucional transformadora. São Paulo: Saraiva, 1996.

BRASIL. Decreto-Lei $n^{\circ} 3.689$, de 3 de outubro de 1941. Código de Processo Penal. Disponível em: http://www.planalto.gov.br/ccivil_03/decreto-lei/Del3689.htm. Acesso em: 29 ago. 2017.

BRASIL. Decreto-Lei $n^{\circ}$ 5.452, de 1 de maio de 1943. Aprova a Consolidação das Leis do Trabalho. Disponível em: http://www.planalto.gov.br/ccivil_03/decreto-lei/Del5452.htm. Acesso em: 29 ago. 2017.

BRASIL. Constituição da República Federativa do Brasil de 1988. Disponível em: http://www.planalto.gov.br/ccivil_03/constituicao/constituicaocompilado.htm. Acesso em: 25 ago. 2017.

BRASIL. Lei $n^{o}$ 8.112, de 11 de dezembro de 1990. Dispõe sobre o regime jurídico dos servidores públicos civis da União, das autarquias e das fundações públicas federais. Disponível em: http://www.planalto.gov.br/ccivil_03/leis/L8112cons.htm. Acesso em: 10 ago. 2017.

BRASIL. Decreto 678, de 6 de novembro de 1992. Promulga a Convenção Americana sobre Direitos Humanos (Pacto de São José da Costa Rica), de 22 de novembro de 1969. Disponível em: http://www.planalto.gov.br/ccivil_03/decreto/d0678.htm. Acesso em: 29 ago. 2017.

BRASIL. LC $n^{o}$ 80, de 12 de janeiro de 1994. Organiza a Defensoria Pública da União, do Distrito Federal e dos Territórios e prescreve normas gerais para sua organização nos Estados, e dá outras providências. Disponível em: http://www.planalto.gov.br/ccivil_03/leis/lcp/Lcp80.htm. Acesso em: 25 ago. 2017. 
BRASIL. Lei $n^{\circ}$ 8.906, de 04 de julho de 1994. Dispõe sobre o Estatuto da Advocacia e a Ordem dos Advogados do Brasil (OAB). Disponível em: http://www.planalto.gov.br/ccivil_03/leis/L8906.htm. Acesso em: 25 ago. 2017.

BRASIL. Lei $n^{o}$ 9.099, de 26 de setembro de 1995. Dispõe sobre os Juizados Especiais Cíveis e Criminais e dá outras providências. Disponível em: http://www.planalto.gov.br/ccivil_03/leis/L9099.htm. Acesso em: 28 ago. 2017.

BRASIL. Lei $n^{\circ}$ 9.307, de 23 de setembro de 1996. Dispõe sobre a arbitragem. Disponível em: http://www.planalto.gov.br/ccivil_03/leis/L9307.htm. Acesso em: 25 ago. 2017.

BRASIL. Lei $n^{\circ}$ 9.784, de 29 de janeiro de 1999. Regula o processo administrativo no âmbito da Administração Pública Federal. Disponível em: http://www.planalto.gov.br/ccivil_03/leis/L9784.htm. Acesso em: 25 ago. 2017.

BRASIL. Lei $n^{o} 10.259$, de 12 e julho de 2001. Dispõe sobre a instituição dos Juizados Especiais Cíveis e Criminais no âmbito da Justiça Federal. Disponível em: http://www.planalto.gov.br/ccivil_03/leis/LEIS_2001/L10259.htm. Acesso em: 25 ago. 2017.

BRASIL. Lei $n^{o} 13.105$, de 16 de março de 2015. Código de Processo Civil. Disponível em: http://www.planalto.gov.br/ccivil_03/_ato2015-2018/2015/lei/113105.htm. Acesso em: 29 ago. 2017.

BRASIL. STF. Súmula 523 - "No processo penal, a falta da defesa constitui nulidade absoluta, mas a sua deficiência só o anulará se houver prova de prejuízo para o réu”. Tribunal Pleno. Brasília, DJ 10 dez.1969.

BRASIL. Supremo Tribunal Federal. $R v C$ 4.886/SP, Tribunal Pleno. Rel. Min. Sepúlveda Pertence. Brasília, DJ 23 abril 1993.

BRASIL. Supremo Tribunal Federal. MS 25.917/DF, Tribunal Pleno. Rel. Min. Gilmar Mendes, Brasília, DJ 1 set. 2006.

BRASIL. STF. Súmula Vinculante no 5 - "A falta de defesa técnica por advogado no processo administrativo disciplinar não ofende a Constituição”. Tribunal Pleno. Brasília, DJ 16 maio 2008.

BRASIL. Supremo Tribunal Federal. RE 434.059/DF, Tribunal Pleno. Rel. Min. Gilmar Mendes. Brasília, DJ 12 set. 2008.

BRASIL. Supremo Tribunal Federal. RE 398.269/RS, $2^{\text {a }}$ Turma. Rel. Min. Gilmar Mendes, Brasília, DJ 26 fev. 2010.

BRASIL. Supremo Tribunal Federal. HC 98.237/SP. 2 ${ }^{\text {a }}$ Turma. Rel. Min. Celso de Mello, Brasília, DJ 6 ago. 2010.

BRASIL. Supremo Tribunal Federal. $R c l$ 9.340/SP, Tribunal Pleno. Rel. Min. Ricardo Lewandowski, Brasília, DJ 5 set. 2014. 
CARVALHO, Kildare Gonçalves. Direito constitucional. $11^{\mathrm{a}}$ ed., rev. e atual. Belo Horizonte: Del Rey, 2005.

ESSENCIAL. Houaiss eletrônico. Versão multiusuário 2009.8. São Paulo: Objetiva, 2014.

GRAU, Eros Roberto. Ensaio e discurso sobre a interpretação/aplicação do Direito. $3^{\mathrm{a}}$ ed. São Paulo: Malheiros, 2005.

HESSE, Konrad. A Força Normativa da Constituição. Tradução de Gilmar Ferreira Mendes. Porto Alegre: Sérgio Antônio Fabris, 1991.

OLIVEIRA, José Roberto. Os princípios da razoabilidade e da proporcionalidade no Direito Administrativo brasileiro. Coleção Temas de Direito Administrativo 16. São Paulo: Malheiros, 2006.

REALE, Miguel.Estrutura e fundamento da ordem jurídica. Revista de Informação Legislativa. Ano 9, n. 36, p. 245-252, out./dez., 1972.

REALE, Miguel. $O$ direito como experiência. Introdução à epistemologia jurídica. $2^{\text {a }}$ ed. São Paulo: Saraiva, 2002.

RIBAS, Antônio Joaquim. Direito Administrativo Brasileiro. Noções preliminares. Rio de Janeiro: F. L. Pinto e C, Livreiros-editores, 1866.

SILVA, José Afonso da. Aplicabilidade das normas constitucionais. $3^{\text {a }}$ ed. São Paulo: Malheiros, 1998.

SUNDFELD, Carlos Ari. Fundamentos de direito público. $4^{\mathrm{a}}$ ed. São Paulo: Malheiros, 2002.

THEODORO JÚNIOR, Humberto. Curso de Direito Processual Civil - Teoria geral do direito processual civil e processo de conhecimento - vol. I. Rio de Janeiro: Forense, 2014.

Data de Submissão: 20/09/2019

Data de Aceite: 29/04/2020 